\title{
EDUCATIONAL PRODUCTION AS A DETERMINING FACTOR IN SOCIETY DEVELOPMENT
}

\author{
Tetiana VLASYUK ${ }^{1}$ \\ Academic Institute of Contemporary Technologies, \\ Kyiv National University of Technologies and Design, Ukraine
}

\begin{abstract}
A new paradigm for economic development of higher educational institutions of Ukraine requires appropriate institutional support. The reality of domestic transients is the imperfection of institutions, which corresponds to the mixed economy of market type and adequately represents the norms and stereotypes of behavior in the spheres of income distribution regulation, employment, social security, health, education. The purpose of the paper is to study the role of educational production as a determining factor in economic development of society. Methodology. In the researching process general scientific and special methods of the studying processes and facts were used in their correlation and development. Among them: monographic - in the forming of the research subject and object; induction and deduction - in the determining of the means, objects of the labour and factor of educational production; the method of the systematic studying the business processes - in the determining of the interaction of the main components of the educational production. Results. The cause of any production is needs availability. To meet his needs the person should enter into business relations with other people that is the basis of market relations. A key resource of the economy, the main engine of development perform is the knowledge which is also an important criterion for successful adaptation of a man in society. Accordingly, in society, the role of education as a sphere of production, exchange, consumption of knowledge is increasing. The received knowledge, skills and other competences by the individual is the end result of educational process. Knowledge is one of the main elements of intellectual property and intellectual capital, and it contributes to the development of the macroenvironment, namely, labor and scientific potential of the state. Each high school, its scientific and innovative activity, its financial bases of development, depends on the efficiency of using new knowledge. Value/originality. It is established that the main components of educational process are: at the macro level - the needs of society, state, educational environment and resources; at the micro level - activities in the field of education and science, individual, scientific and pedagogical workers, the interaction of whom leads to the transmission, assimilation, augmentation and use of knowledge, skills and other competencies.
\end{abstract}

Key words: knowledge, education, manufacturing, educational process, educational results, educational production components.

JEL Classification: I 121, | 123, I 125, P 41

\section{Problem statement}

The active process of market relations formation in Ukraine is radically changing economic environment. Economic entities operate in the new sphere; the key characteristics (competitive, financial, tax, etc.) are in the process of market formation. The activities of economic entities acquire dynamic character, characterized by competition, responsibility for the results, initiative, risk, etc. In such circumstances, the activity of not only the manufacturing sector enterprises is changing, but many of social institutions are as well (Padalka \& Kalenyuk, 2012).

The effective functioning of the education sector requires the introduction of responsibility elements for the results of their activities, the flexibility and adaptability of educational institutions as for the changing conditions of the labour market, competition and the like.

A new paradigm for economic development of higher educational institutions of Ukraine requires appropriate institutional support. The reality of domestic transients is the imperfection of institutions, which correspond to the mixed economy of market type and adequately represent the norms and stereotypes of behavior in the spheres of income distribution regulation, employment, social security, health, education. Therefore, the study of educational production as an institutional factor of national economy innovative development is relevant.

\footnotetext{
Corresponding author:

${ }^{1}$ Department of Accounting and Auditing, Academic Institute of Contemporary Technologies,

Kyiv National University of Technologies and Design.

E-mail:vlasuk@bk.ru
} 


\section{Review of recent publications}

A significant contribution to the study of economic aspects of higher education development in Ukraine was made by such national scientists as E. Agababian, P. Drucker, L. Fedulova, A. Gazaliev, I. Hryshchenko, I. Kaleniuk, O. Padalka, Y. Pak, O. Pashchenko, A. Toffler, $\mathrm{H}$. Toffler, L. Yakovenko and other.

The analysis and generalization of literary sources and special scientific research has shown that scholars have devoted attention to the development strategies of higher education in their writings. At the same time there are issues in economic literature that are not sufficiently covered, they are connected with the study of education as a process of educational production.

The necessity of studying this problem at the appropriate level and taking into account the specifics and peculiarities of the economic situation in Ukraine led to the theme of the article and identified its purpose and goals.

\section{Key research findings}

As the result of social production process is the creation of tangible and intangible products, so structurally it is divided into two major areas: material (industry; agriculture and forestry; construction; personal services; and utilities and service that are providing financial services; transport; communications; trade) and nonmaterial production (health, education, science, culture, art, sports, tourism, spiritual production).

The cause of any production is needs availability. Needs are objective conditions of human existence, the basis of their physiological, social, intellectual and spiritual reproduction. To meet his needs the person should enter into business relations with other people that is the basis of market relations.

The researchers claim that at a certain stage of development the material production began to demand a qualitatively new source of economic growth in the form of scientific progress, which in its turn ensures the production of intelligent products (Yakovenko \& Pashchenko, 2011).

A key resource of the economy, the main engine of development perform is the knowledge which is also an important criterion for successful adaptation of a man in society. Accordingly, in society, the role of education as a sphere of production, exchange, consumption of knowledge is increasing, but also it is becoming a center of material and spiritual culture.

Traditionally the main features, properties and characteristics of knowledge are highlighted in the literature. In particular, A. Toffler in his work «Revolutionary wealth» sufficiently gives inherent features of knowledge, stressing their fundamental difference from other resources involved in the creation of wealth (Toffler, 2008):

- knowledge in its essence is not an object of competition, that's why many people use the same knowledge, volume of which is not reduced. On the contrary, the more people use the knowledge, the higher the probability is that someone will develop new knowledge based on them; - knowledge is intangible, it is impossible to touch, but they can be used;

- knowledge is non-linear, even a single discovery may make a huge effect;

- knowledge is relative, for even a single fragment acquires a meaning only in the context of other fragments, creating a context;

- knowledge is combined with other knowledge; the more knowledge, the more varied and useful their combinations;

- knowledge as the most mobile product can instantly be broadcast over vast distances;

- knowledge can be compressed into symbols and abstractions, on contrary from any material object;

- knowledge can be stored in the smallest cells.

A. Toffler noted that economists found out themselves face to face with the system of wealth that, for decades, has lost their dependence on resources that are exhausted, making its way to the main factor of its growth - knowledge (Toffler, 2008).

P. Drucker argues that in the new economy, knowledge is the only resource that has sense amongst the traditional factors of production (labour, land and capital) (Drucker, 2007).

L. Fedulova defines such forms of knowledge: 1) individual (subjective) knowledge as the system of acquired or developed concepts that mediate the relationship of a man to reality;2) codified knowledge, which is represented in a symbolic form or in the form of symbols (verbal or written test, formulas, drawings); 3) objective knowledge as an intellectual model, embodied in the objective form of activities processes, its tools and results (Fedulova, 2009).

So, if we analyze the knowledge on the grounds above, it becomes clear that we are dealing with what is not consumed and not spent in the conventional sense. The dynamic nature of the educational production gives it the characteristics of the process; so we are talking here about the process of educational production.

The process is a set of sequential actions to achieve certain goals and results, in which there is a change or transformation of the surrounding world, activity ordering, etc. The educational process is an intellectual, creative activity in the field of higher education and science, which is carried out in a higher educational institution (scientific institution) via the system of scientific-methodical and pedagogical activities and is aimed at the transfer, assimilation, multiplication and use of knowledge, skills and other competences of people who are studying, as well as the formation of a harmoniously developed personality (Law of Ukraine «About the higher education», 2014).

It is possible to show the schematic process of educational production (Figure 1).

That is the result of learning is the combination of knowledge, skills, abilities, and other qualities acquired by the person during the learning process in certain educational and professional or educational and scientific 
program which can identify, quantify and measure (Law of Ukraine «About the higher education», 2014).

In education, the main factor stimulating changes is a rapidly increasing flow of information. This requires ongoing changes to the content of the educational process. The period of time over which the volume of knowledge doubles is significantly reduced: since 1900 for 50 years, since 1950 - 10 years, since 1970 - every year, since 1990 every year.

In the context of globalization, every worker to maintain the level of preparedness in accordance with the requirements of society and the labour market needs to replenish his intellectual potential. Such activity is called education for life and is a purposeful process of mastering the professional competences that allow the person to remain functional throughout his life. Earlier the share of such people among the economically active population was negligible, but today lifelong learning is a necessary attribute of a modern society based on knowledge (Gazaliev \& Pak, 2016).

That is, an educational production has the following features: a high proportion of intellectual work of creative nature, a certain degree of novelty generating useful effect, the conditionality of the last interaction of the object and the subject of activity, direct impact on consumers of intellectual products, the ability to be accumulated in various forms of spiritual wealth (Agababian, 2003). Thus, the subjects of educational process are the educational institutions and separate research and teaching staff, and objects - separate individuals (education applicants), who are users of the educational production results.

We believe that the educational production should be viewed as the process of creating educational products in the process of interaction of subject and object of the educational environment expressed by the acquired knowledge, skills and other competencies of the individual that lead to beneficial effects.

In the process of educational production there is an interaction of means and objects of the labour that fit into the classical scheme of the production: 1) the object of labour is an individual; 2) the means of production are educational programs and services, provided by financial, logistical, informational and educational resources; 3) goods are acquired knowledge, skills and other competencies; 4) additional services are culturalconsumer services (dorms, canteens, gyms, printing center, medical center, the centers of culture and arts).

Any educational product is created as a result of the conversion of economic resources (factors of production). In economic theory labour, land and capital are generally considered to be the main economic factors (Marx, 1954).

The labour is primarily a process that occurs between a teacher and a student during learning. The labour in its educational process includes, first of all, the work of teachers. The teacher is the central figure of the educational process, he has to affect the real educational condition of educational process at universities and take the measures necessary to improve the economic efficiency of the educational process. Another educational factor of production is land, as an economic category. The term «land» includes all natural resources that are used to produce educational products. The land is used for academic buildings, structures, buildings, housing for teachers, stadiums, sports facilities, transport infrastructure, recreation areas, etc, acts as the development of human capital, public and individual welfare. To ensure the functioning of educational institutions we need the necessary logistical tools that make up the group of the resource economic capital (capital and current assets). These assets include buildings, computer equipment, furniture, laboratory equipment, library fund, etc. They are necessary for the functioning of higher education institutions and supporting the educational process (Gryshchenko, 2016).

The process of educational production is dependent on the development of the educational environment in which each educational institution operates separately. The micro level of the educational environment includes educational institutions, families, direct communication; macro-level social, cultural, ideological, economic, technological, political, legal, religious, and ethnic factors.

Educational production has also its own specifics, connected with state intervention and regulation activities through the development and implementation of complex

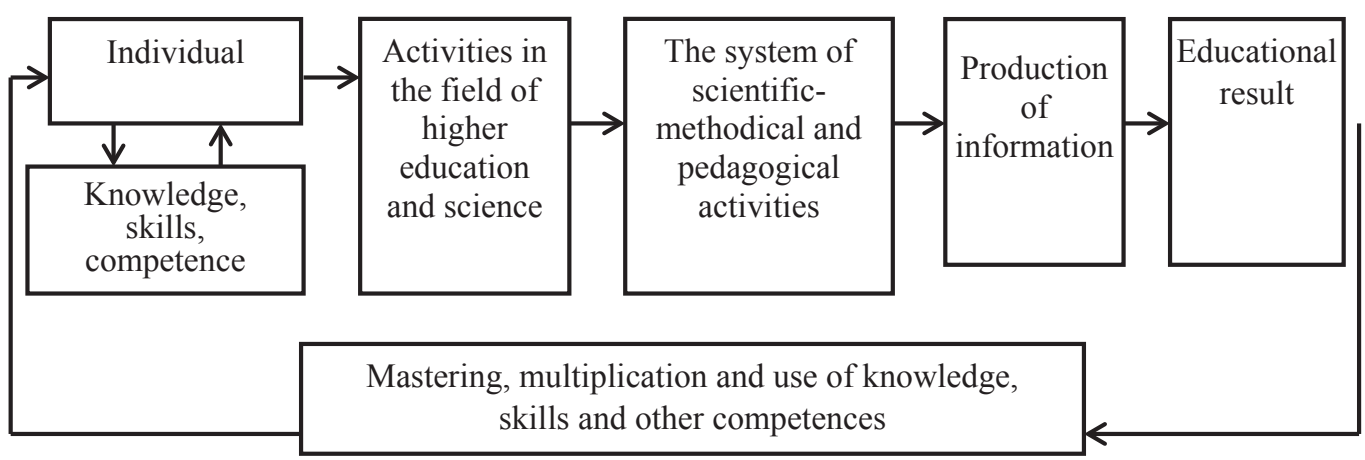

Fig. 1. The process of educational production

Source: developed by the authors 
public policies that take into account the legitimate rights and interests of the individual and society.

Therefore, the interaction of the main components of the educational production can be represented as follows (Figure 2).

Educational production begins with the development of individual needs, the level of which is influenced by the development of the state and educational environment; the educational environment development depends on the availability of resources and societal needs; available resources are influenced by innovative development of the educational environment and public policy; and correspondingly the development of a state is influenced by available resources and the society needs.

The microenvironment of educational process is formed by the interaction of individuals (objects of the educational production) and activities in the field of education and science (education subject), expressed in the educational process, the result of which is to obtain certain competencies. The results of the activity are also research and innovation developments done by scientists of the high institutions, and are used to produce a useful effect and contribute to the development of the state.

That is, the process of educational production can be expressed with one of the dialectics laws, the continuous in-depth knowledge, which suggests that the process of disclosing new aspects of development should be viewed as an infinite learning from a phenomenon to an essence, that has been steadily increasing, from a less profound essence to a more profound one, as the repetition at the highest stage of the known characteristics and properties of the upper stage, that is, negation of negation. The law unites analysis and synthesis as major components of the cognition. Educational production is a chain of dialectical negations, each of which not only negates the previously accumulated experience, but also preserves the positive aspects in it, increasingly concentrating wealth development in general.

\section{Conclusions}

In recent years, the volume of knowledge in society doubles every year, that significantly increases the importance of the education production, which is a key resource for the society development. That is, education is ready to prepare the new generation of professionally knowledgeable people. In this case the dominant process is the growing intensity of knowledge that contributes to the transformation of the world into a world without borders.

The received knowledge, skills and other competences by the individual are the end result of educational process. Knowledge is one of the main elements of intellectual property and intellectual capital, and it contributes to the development of the macroenvironment, namely, labor and scientific potential of the state. Each high school, its scientific and innovative activity, its financial bases of

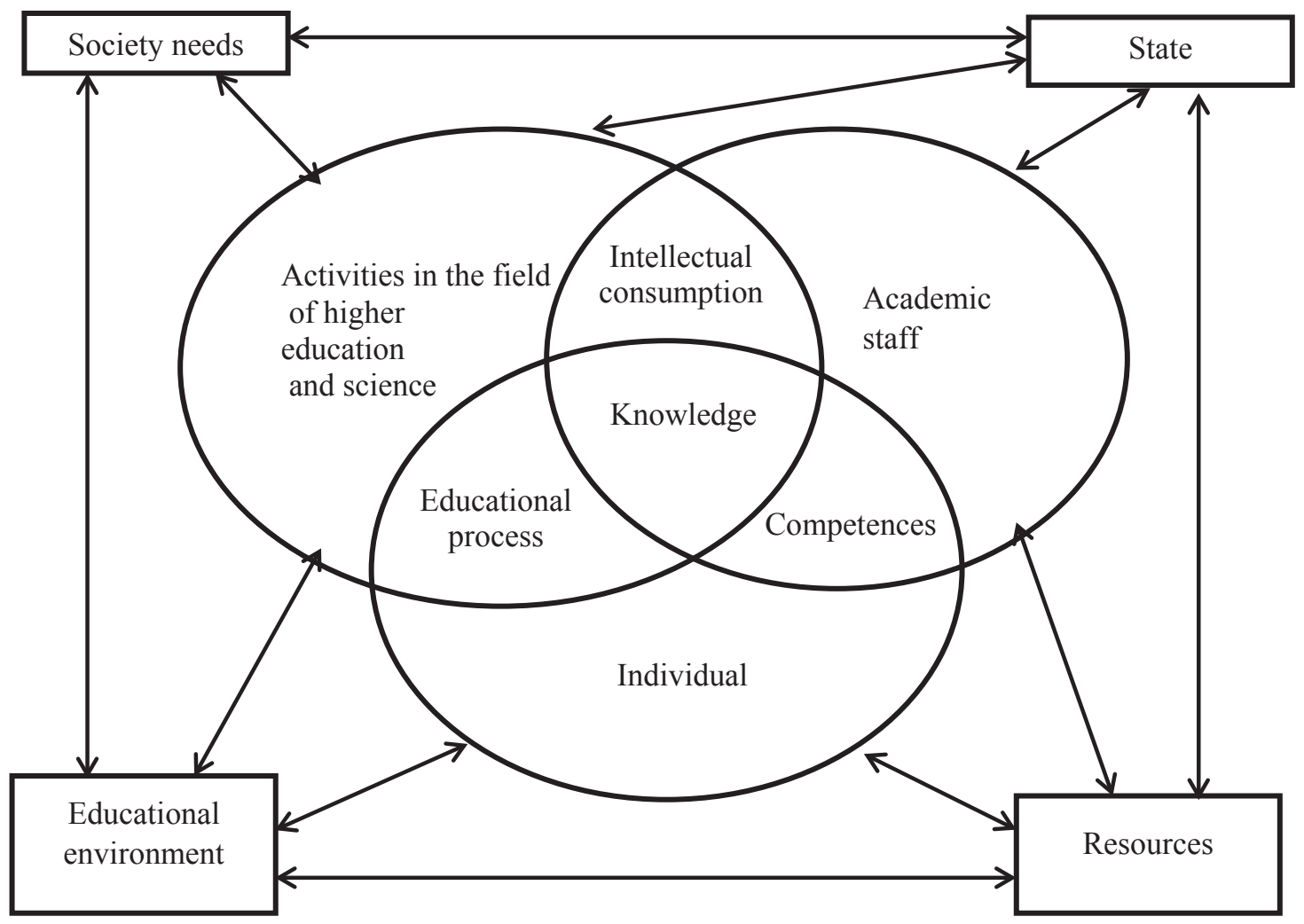

Fig. 2. The interaction of the main components of the educational production

Source: developed by the authors 
development, depends on the efficiency of using new knowledge.

The educational production process largely depends on the level of economic development of separate components of university activities, therefore in further studies it is appropriate to focus on the development of the analysis methodology and regulation of this activity in higher education.

\section{References}

Of higher education: the Law of Ukraine dated 01.07.2014 № 1556-VII / zakon3.rada.gov.ua/laws/show/1556-18 Agababian, E. (1985). Global economy of intellectual services: status, trends and regulation. Problems of theory and management practice, $6: 25-30$.

Gazaliev, A. M. \& Pak, Y. N. (2016). Innovative potential of higher school in the context of globalization of education. Bulletin of higher school «Alma Mater», 2: 16-22.

Gryshchenko, I. M. (2016). Factors of increasing efficiency of educational activity at higher educational establishments of Ukraine. Actual problems of economy, 3: 134-141.

Drucker, P. F. (2007). Age of discontinuity: guidelines to our changing society. Moscow: Williams, I. D.

Marx, K. (1954). Capital. Critique of political economy. The process of production of capital. Kiev: State... USSR. Padalka, O. S. \& Kalenyuk, I. S. (2012). Economics of education and management. Kiev: Pedagogical thought.

Toffler, A. \& Toffler, H. (2008). Revolutionary wealth: how it will be created and how it will change our lives. Moscow: AST MOSCOW: Profizdat.

Fedulova, L. I. (2009). Economy of knowledge. Kiev: NAS of Ukraine, Institute of Economics and forecasting of NAS of Ukraine.

Yakovenko, L. I. \& Pashchenko, O. V. (2011). Economic framework for the modernisation of higher education in terms of knowledge economy. Poltava: Scitec.

\section{Татьяна ВЛАСЮК}

\section{ОБРАЗОВАТЕЛЬНОЕ ПРОИЗВОДСТВО КАК ОПРЕДЕЛЯЮЩИЙ ФАКТОР РАЗВИТИЯ ОБЩЕСТВА}

Аннотация. Новая парадигма экономического развития высших учебных заведений Украины требует соответствующей институциональной поддержки. Реальностью же национальных переходных процессов является несовершенство институтов, которые соответствуют смешанной экономике рыночного типа и адекватно представляют нормы и стереотипы поведения в сфере регулирования распределения доходов, занятости, социального обеспечения, здравоохранения, образования. Целью исследования является изучение роли образовательного производства как определяющего фактора в экономическом развитии общества. Методика. В процессе исследования были использованы общенаучные и специальные методы процессов и фактов в их взаимосвязи и развития. Среди них: монографический - при формировании предмета исследования и объекта; индукции и дедукции - при определении средств, предметов труда и фактора образовательного производства; метод систематического изучения бизнес-процессов - при определении взаимодействия основных компонентов образовательного производства. Результаты. Причиной любого производства является наличие потребностей. Для удовлетворения своих потребностей человек вступает в деловые отношения с другими людьми, что является основой рыночных отношений. Ключевым ресурсом экономики, основным двигателем развития являются знания, которое также выступают важным критерием для успешной адаптации человека в обществе. Соответственно в обществе, роль образования как сферы производства, обмена, потребления знаний постоянно растет. Полученные знания, навыки и другие компетенции отдельного индивида является конечным результатом образовательного процесса. Знание - основой элемент интеллектуальной собственности и интеллектуального капитала, и это вносит свой вклад в развитие макросреды, а именно, труда и научного потенциала государства. Каждое учебное заведение, его научная и инновационная деятельности, его финансовая основа развития, зависит от эффективности использования новых знаний. Значение/оригинальность. Установлено, что основными составляющими образовательного процесса являются: на макроуровне - потребности общества, государство, образовательная среда и ресурсы; на микроуровне - деятельность в области образования и науки, отдельный индивид, научно-педагогический работник, взаимодействие которых приводит к передаче, ассимиляции, увеличении и использовании знаний, навыков и других компетентностей. 